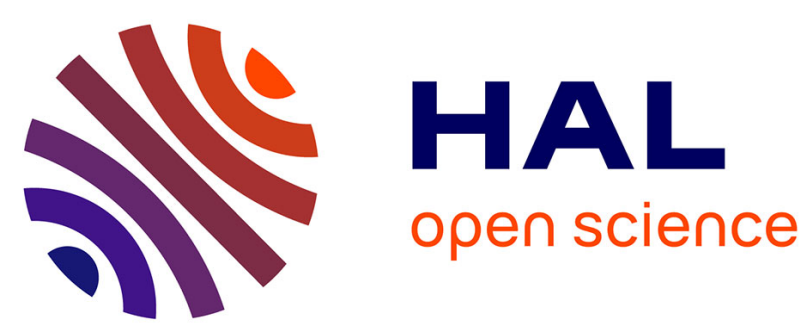

\title{
Clinical efficacy of arsenic trioxide in a patient with acute promyelocytic leukemia with recurrent central nervous system involvement
}

Patrizia Zappasodi, Marianna Rossi, Ilaria Ambaglio, Paolo Bernasconi, Alessandro Corso, Mario Lazzarino, Carlo Castagnola

\section{To cite this version:}

Patrizia Zappasodi, Marianna Rossi, Ilaria Ambaglio, Paolo Bernasconi, Alessandro Corso, et al.. Clinical efficacy of arsenic trioxide in a patient with acute promyelocytic leukemia with recurrent central nervous system involvement. Annals of Hematology, 2010, 90 (5), pp.595-597. 10.1007/s00277010-1046-6 . hal-00583548

\section{HAL Id: hal-00583548 \\ https://hal.science/hal-00583548}

Submitted on 6 Apr 2011

HAL is a multi-disciplinary open access archive for the deposit and dissemination of scientific research documents, whether they are published or not. The documents may come from teaching and research institutions in France or abroad, or from public or private research centers.
L'archive ouverte pluridisciplinaire HAL, est destinée au dépôt et à la diffusion de documents scientifiques de niveau recherche, publiés ou non, émanant des établissements d'enseignement et de recherche français ou étrangers, des laboratoires publics ou privés. 
Clinical efficacy of arsenic trioxide in a patient with acute promyelocytic leukemia with recurrent central nervous system involvement

Zappasodi P, Rossi M, Ambaglio I, Bernasconi P, Corso A, Lazzarino M, Castagnola C.

Division of Hematology, Foundation IRCCS Policlinico San Matteo, University of Pavia, Italy.

Keywords: APL, arsenic trioxide, CNS, central nervous system localization

The authors have no commercial or other associations that might pose a conflict of interest in connection with the submitted paper.

Correspondence to:

Patrizia Zappasodi MD

Division of Hematology

IRCCS Policlinico San Matteo

27100 Pavia, Italy

Tel. (39) 382503095

Fax (39) 382502250

E-mail: p.zappasodi@smatteo.pv.it 


\section{Dear Editor,}

Central nervous system (CNS) involvement is rare in acute promyelocytic leukemia (APL). Its incidence at relapse does not usually exceed $2 \%$ and it occurs more frequently in patients with hyperleukocytosis at presentation and in presence of prior CNS hemorrhage during induction $(1,2)$. Although the treatment of APL has been revolutionized by the specific targeted action of all-trans retinoic acid (ATRA) and more recently by the introduction of arsenic trioxide (ATO), a sizeable proportion of patients still relapse. Moreover, as for all types of acute leukemia, extramedullary sites of disease are very difficult to control and CNS involvement represents a particular challenge for which definite therapeutic information is lacking. As for acute lymphoblastic leukemia, intrathecal chemotherapy is indicated in combination with systemic high dose cytarabine (2); however, resistance and toxicity frequently limit durable disease control. ATO has dual dose-dependent effects in APL, inducing differentiation at low concentrations and apoptosis at higher concentrations. Elemental arsenic has been detected in the cerebrospinal fluid (CSF) of patients receiving ATO $(3,4)$, reflecting the ability of CNS penetration of arsenic though significantly varying among patients. So far, it has been suggested that arsenic in the CSF could be beneficial in APL with CNS involvement (5). However, although ATO has been demonstrated to be effective in the treatment of some extramedullary sites of APL (6), no clinical results have ever been reported in patients with CNS disease. We report here the case of a 39-year old woman with advanced APL with disease relapse in the CNS who was successfully treated with ATO single agent.

The patient was diagnosed as having low-risk APL when she was 34 years old; principal information about her clinical history is summarized in table 1. First relapse, occurred after 2 years of complete molecular remission, was treated with chemotherapy followed by autologous stem cell transplantation because of the lack of an available related or unrelated donor, but only 3 months later she developed headache and paresthesia of the right arm due to the presence of PML-RAR $\alpha$, bcr1-positive blasts evidenced in the CSF, while bone marrow still showed molecular complete remission. Despite a combined systemic and intrathecal chemotherapy was given followed by cranial radiotherapy and ATRA maintenance, CSF blasts infiltration persisted. She therefore received intrathecal liposomal cytosine arabinoside (lipAraC), but after the second dose she suddenly developed mental confusion and agitation, suggesting an acute neurological toxicity caused by the lipAraC which was, therefore, stopped. The psychiatric symptoms progressively receded over the following week while a good response, with no detectable blast cells and PML-RAR $\alpha$ was documented in CSF. A few months later a third relapse consistent with bone marrow and CSF blasts was treated with ATO $9 \mathrm{mg} / \mathrm{die}$ and weekly intrathecal methotrexate followed by three-weekly consolidation cycles with ATO 9 mg/die and ATRA. At completion of this treatment, CSF was PCR-positive but without evidence of blasts. After only 4 months of well-being, neurological symptoms recurred and the disease progressed also in bone 
marrow. Treatment with idarubicin and ATRA combined with intrathecal cytarabine achieved only a bone marrow morphological response. Given the neurological symptoms worsening (tetraplegia, confusion) a magnetic resonance (MR) imaging of the brain was carried out, showing diffuse meningeal lesions consistent with disease localizations. She was then administered systemic steroids but her conditions worsened further on and more diffuse leptomeningeal lesions with thrombosis of the superior sagittal sinus were documented (fig.1). A new course of ATO single agent was given and during treatment, lasting 25 days, neurological manifestations improved, molecular complete remission in bone marrow was achieved and we found a marked reduction of blast cells in the CSF. The patient was discharged and, after four additional courses of ATO (5 days/week for 4 weeks alternated with 4 weeks off), even if CSF was not evaluable for molecular assessment, the cytocentrifugate was negative and MR showed meningeal lesions with reduced thickness and contrast enhancement, as well as resolution of the pathological tissue previously described in the superior sagittal sinus (fig. 2). During consolidation therapy we measured plasma and CSF levels of arsenic (134 mcg/l and $15 \mathrm{mcg} / \mathrm{l}$, respectively), confirming that ATO had penetrated into the CNS. Our patient is still in complete remission at her most recent evaluation, one year after the last relapse and three months after the last administration of ATO.

The case presented is paradigmatic of acute promyelocytic leukemia, which, despite the low risk at presentation and the molecular remission obtained after induction, can undergo a long series of relapses, in some cases involving the CNS. The peculiarity of this case is, however, a patient's marked sensitivity to ATO which allowed good control of the disease in two distinct relapses, including in the CNS characterized by diffuse leptomeningeal lesions. The severity of this clinical picture, occurring in an advanced phase of disease, initially led us to consider that any other therapy would be unsuccessful. If this patient had been treated in the pre-ATO era, she probably would not have had an improvement of neurological symptoms because of the resistance demonstrated to ATRA, high-dose systemic cytarabine, intrathecal cytarabine and methotrexate. She did, however, show an unexpected response to ATO also in the last retreatment as single agent, even though the disease involved a "leukemic sanctuary", in this case the CNS. Arsenic was detectable in the CSF, although its level was measured only once during treatment and we cannot define a therapeutic level. However, in our opinion, the clear improvement of the disease in both the CSF and in the brain induced by ATO is important new information which opens promising possibilities of controlling this severe complication. We do not know how long the CNS disease control achieved with ATO will be maintained or whether maintenance therapy with ATO could be beneficial in prolonging response. Nevertheless, this case report, highlighting the efficacy of ATO also for recurrent relapses of APL involving the CNS, suggests that further large studies investigating the effects of ATO in this particular context are warranted. 
Table 1

Bone marrow and CSF data during clinical history

\begin{tabular}{|c|c|c|c|c|c|c|}
\hline & Diagnosis & $1^{\text {st }}$ relapse & $2^{\text {nd }}$ relapse & $3^{\text {rd }}$ relapse & Progression & $\begin{array}{c}\text { Further } \\
\text { progression }\end{array}$ \\
\hline $\begin{array}{c}\text { Bone } \\
\text { Marrow } \\
\text { status }\end{array}$ & $\begin{array}{c}\text { Blasts } \\
\text { PMLRAR } \alpha+\end{array}$ & PMLRAR $\alpha+$ & $\begin{array}{c}\text { CR, } \\
\text { PMLRAR } \alpha-\end{array}$ & $\begin{array}{c}\text { Blasts } \\
\text { PMLRAR } \alpha+\end{array}$ & $\begin{array}{c}\text { CR } \\
\text { PMLRAR } \alpha+\end{array}$ & $\begin{array}{c}\text { Blasts } \\
\text { PMLRAR } \alpha+\end{array}$ \\
\hline $\begin{array}{l}\text { CSF } \\
\text { status }\end{array}$ & NE & NE & $\begin{array}{c}\text { Blasts } \\
\text { PMLRAR } \alpha+\end{array}$ & $\begin{array}{c}\text { Blasts } \\
\text { PMLRAR } \alpha+\end{array}$ & $\begin{array}{c}\text { Blasts } \\
\text { PML-RAR } \alpha+\end{array}$ & $\begin{array}{c}\text { Blasts } \\
\text { PMLRAR } \alpha+\end{array}$ \\
\hline Treatment & AIDA & $\begin{array}{c}\text { AIDA+Auto } \\
\text { Tx }\end{array}$ & $\begin{array}{c}\text { Ida+HDAraC, } \\
\text { IT-lipAraC, IT- } \\
\text { MTX, cranial } \\
\text { RT, ATRA }\end{array}$ & $\begin{array}{l}\text { ATO+ATRA, } \\
\text { IT-MTX }\end{array}$ & $\begin{array}{l}\text { Idarubicin+ } \\
\text { ATRA, } \\
\text { IT-AraC }\end{array}$ & ATO \\
\hline $\begin{array}{c}\text { Bone } \\
\text { marrow } \\
\text { response }\end{array}$ & $\begin{array}{c}\text { CR, } \\
\text { PMLRAR } \alpha-\end{array}$ & $\begin{array}{c}\text { CR, } \\
\text { PMLRAR } \alpha-\end{array}$ & $\begin{array}{c}\text { CR, } \\
\text { PMLRAR } \alpha-\end{array}$ & $\begin{array}{l}\text { CR, PML- } \\
\text { RAR } \alpha-\end{array}$ & $\begin{array}{c}\text { CR, } \\
\text { PMLRAR } \alpha+\end{array}$ & $\begin{array}{c}\text { CR, } \\
\text { PMLRAR } \alpha-\end{array}$ \\
\hline $\begin{array}{c}\text { CSF } \\
\text { response }\end{array}$ & NE & NE & $\begin{array}{c}\text { CR, } \\
\text { PMLRAR } \alpha-\end{array}$ & $\begin{array}{c}\text { No Blasts, } \\
\text { PMLRAR } \alpha+\end{array}$ & $\begin{array}{c}\text { Blasts } \\
\text { PMLRAR } \alpha+\end{array}$ & No Blasts \\
\hline
\end{tabular}

Legend:

CR: $\quad$ Complete Remission

NE: $\quad$ Not Evaluated

Tx: Transplant

IT-lipAraC: Intrathecal liposomal cytosine arabinoside 


\section{$\underline{\text { References }}$}

1. Montesinos $P$, Dìaz-Mediavilla J, Debén $G$, Prates $V$, Tormo $M$, Rubio V, Pérez I, Fernàndez I, Viguria M, Rayòn C, Gonzàles J, de la Serna J, Esteve J, Bergua JM, Rivas C, Gonzàles M, Gonzàles JD, Negri S, Brunet S, Lowenberg B, Sanz M. Central nervous system involvement at first relapse in patients with acute promyelocytic leukemia treated with all-trans retinoic acid and anthracycline monochemotherapy without intratecal prophylaxis. Haematologica 2009; 94(9): 1242-9.

2. Sanz MA, Grimwade D, Tallman MS, Lowenberg B, Fenaux P, Estey EH, Naoe T, Lengfelder E, Buchner T, Dohner H, Burnett AK, Lo-Coco F. Management of acute promyelocytic leukemia from an expert panel on behalf of the European Leukemia Net. Blood 2009; 113 (9): 1875-91.

3. Kiguchi T, Yoshino Y, Yuan B, Yoshizawa S, Kitahara T, Akahane D, Gotoh M, Kaise T, Toyoda H, Ohyashiki K. Speciation of arsenic trioxide penetrates into cerebrospinal fluid in patients with acute promyelocytic leukemia. Leuk Res. 2009 Sep 3. [Epub ahead of print]

4. Knipp S, Gattermann N, Schapira M, Käferstein H, Germing U.

Arsenic in the cerebrospinal fluid of a patient receiving arsenic trioxide for relapsed acute promyelocytic leukemia with CNS involvement. Leuk Res. 2007 Nov;31(11):1585-7.

5. Au WY, Tam S, Fong BM, Kwong YL. Determinants of cerebrospinal fluid arsenic concentration in patients with acute promyelocytic leukemia on oral arsenic trioxide therapy. Blood. 2008 Nov 1;112(9):3587-90.

6. Kai T, Kimura H, Shiga Y, Ogawa K, Sato H, Maruyama Y.

Recurrent extramedullary relapse of acute promyelocytic leukemia after allogeneic stem cell transplantation: successful treatment by arsenic trioxide in combination with local radiotherapy. Int J Hematol. 2006 May;83(4):337-40. 
Figure 1

Magnetic resonance image showing diffuse leptomeningeal lesions and thrombosis of the superior sagittal sinus (as shown in the circle).

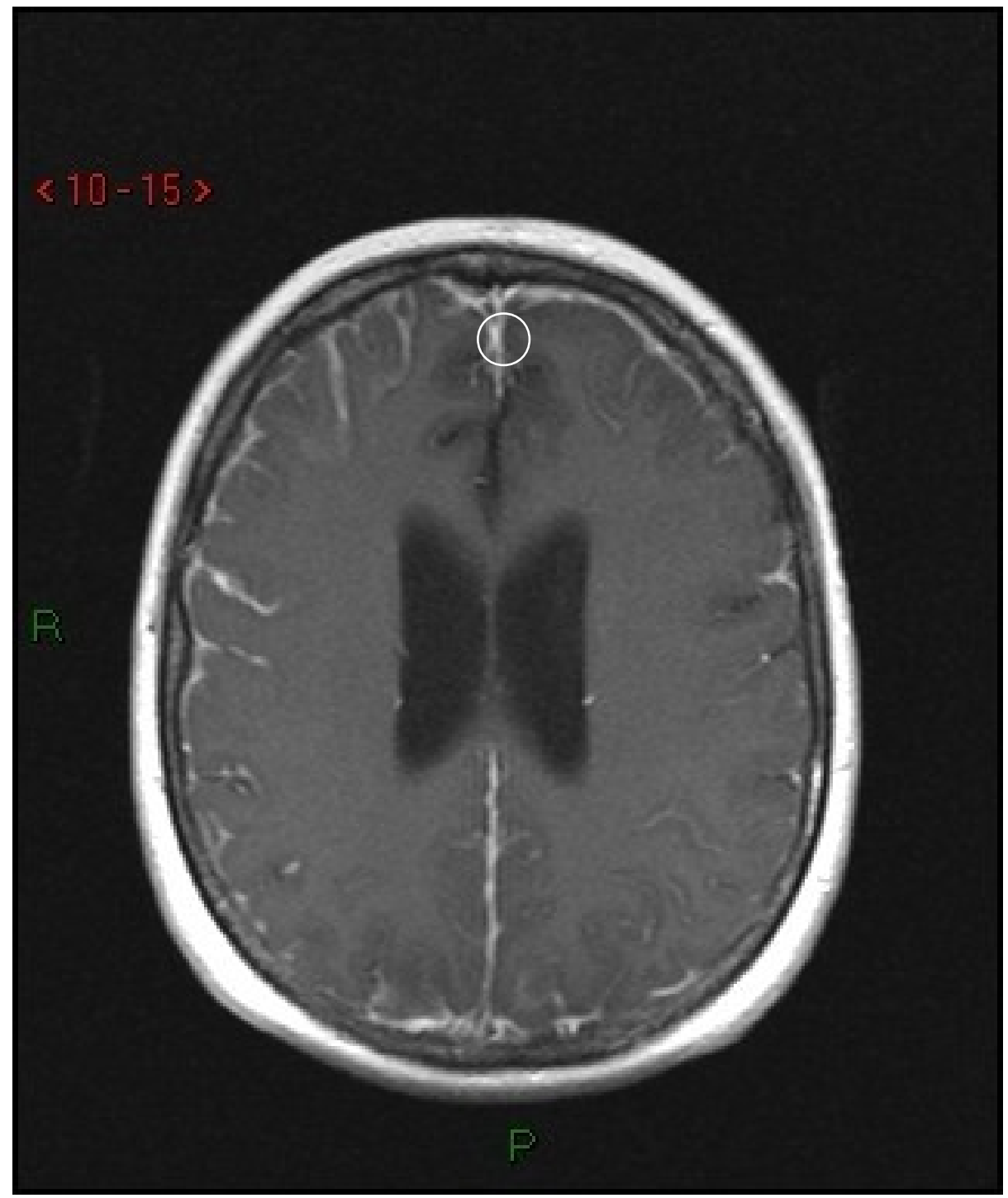


Figure 2

Magnetic resonance image after treatment with single agent arsenic trioxide showing reduced thickness and contrast enhancement of leptomeningeal lesions and resolution of the superior sagittal sinus thrombosis.

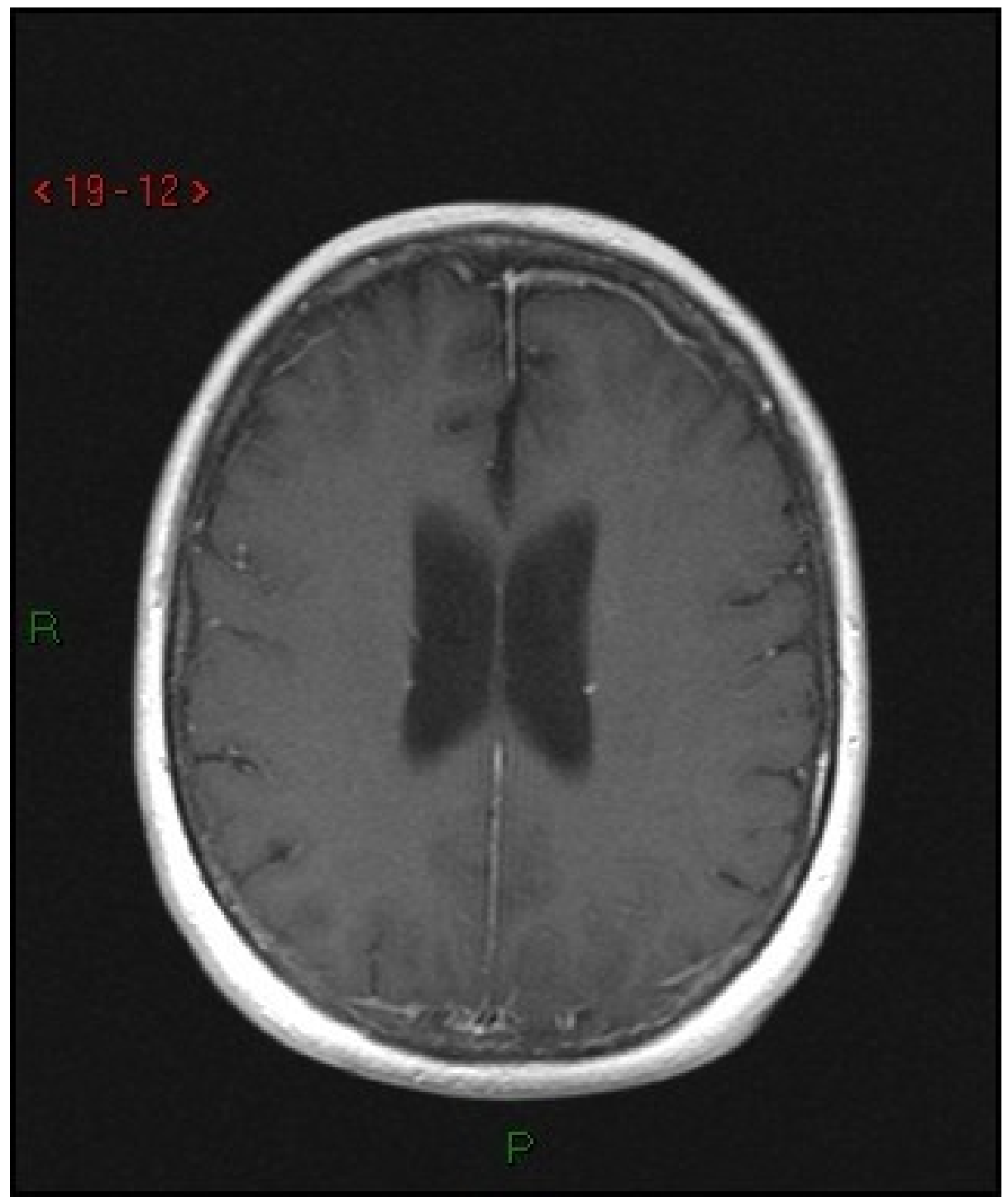

